\title{
PNAE (National School Feeding Program) and Its Events of Expansive Learnings at Municipal Level
}

\author{
Eliane Alves da Silva *, Eugenio Avila Pedrozo and Tania Nunes da Silva
}

check for updates

Citation: da Silva, E.A.; Pedrozo, E.A.; da Silva, T.N. PNAE (National School Feeding Program) and Its Events of Expansive Learnings at Municipal Level. World 2022, 3, 86-111. https://doi.org/ $10.3390 /$ world 3010005

Academic Editor: Mario D’Amico

Received: 7 September 2021

Accepted: 9 February 2022

Published: 15 February 2022

Publisher's Note: MDPI stays neutral with regard to jurisdictional claims in published maps and institutional affiliations.

Copyright: (C) 2022 by the authors. Licensee MDPI, Basel, Switzerland. This article is an open access article distributed under the terms and conditions of the Creative Commons Attribution (CC BY) license (https:// creativecommons.org/licenses/by/ $4.0 /)$.
Program of Post-Graduation in Administration, School of Business Administration, Federal University of Rio Grande do Sul, Porto Alegre 90010-460, Brazil; eugenio.pedrozo@ufrgs.br (E.A.P.); tnsilva@ea.ufrgs.br (T.N.d.S.) * Correspondence: eliane.alves@ufrgs.br

\begin{abstract}
The National School Feeding Program (PNAE for its acronym in Portuguese) is one of the largest food policies in the world, partially covering the daily needs of 44 billion students per year. In 2009, Law No. 11,947 established that at least 30\% of the total financial transfer of PNAE was used in the purchase of foodstuff directly from family farming in the left-wing government of Lula. In practice, the rules allow public policy managers to choose between bidding or public call, provision by large agribusiness companies or by family farmers, and this is practiced in idiosyncratic ways by 5568 Brazilian municipalities. Each municipality organizes its own system. Therefore, the aim of this article is to analyze how the evolution of Law No. 11,947 promotes expansive learning in the Brazilian National School Feeding Program (NSFP-PNAE), located in the Western Amazon. As a theoretical framework, the Cultural-Historical Activity Theory (CHAT) and the Theory of Expansive Learning (TEL) were used. Qualitative research in an abductive reasoning was carried out, using a single and incorporated case study as its strategy. The study included 21 interviews, later analyzed by Content Analysis. The main contribution is the advance in solutions for societal needs, in terms of continuous collective collaboration, creating expansive learning, transformative or not, in both sides of productive systems and consumption, integrating family farmers and students by a healthy nutrition and feeding in the same system since 2009.
\end{abstract}

Keywords: expansive learning; nutritional and feeding program; NSFP-PNAE

\section{Introduction}

The National School Feeding Program (NFSC-PNAE-Programa Nacional de Alimentação Escolar) in Brazil was created in 1979; however, its construction process dates back to 1955, with the School Meal Campaign in the government of Getúlio Vargas (FNDE/PNAE, 2019) [1]. Its main objective is to partially meet the nutritional needs of the beneficiary students by offering at least one meal a day in order to comply with the nutritional requirements for the period in which they are at school. Thus, school meals must cover at least 15\% of the student's daily needs (FNDE, 2019) [2].

The NSFP-PNAE is a policy recognized worldwide as a reference for the implementation of sustainable school feeding programs (Silva, Amparo-Santos and Soares, 2018) [3]. For Maluf and Luz (2016) [4], this good evaluation is due to the fact that the program has instruments that enhance access to adequate and healthy food, resulting in socially inclusive forms of production and distribution, and respecting the various expressions of diversity in the process.

This process of introducing family farming has been improved within the PNAE. Initially, Law 11,947 [5] was instituted on 16 June 2009, and was improved in 2013 with the Resolution of the National Education Development Fund (FNDE) No. 26 [6], later in 2015 with Resolution No. 4 [7] and more recently with Resolution No. 6 of 8 May 2020 [8]. In summary, these initiatives ensure that at least $30 \%$ of the PNAE's financial transfer is directed to the purchase of foodstuff from family farming. It is noteworthy that farmers 
from agrarian reform settlements, traditional indigenous communities and quilombola communities are classified as family farmers.

Law 11,947 [5] implemented the public call, since until 2009, purchases for school meals were exclusively subject to Law No. 8666/93 [9], "Bid Law" (Triches and Schneider, 2010) [10]. Thus, the municipality, through public calls, chooses its supplier, not necessarily being restricted to the lowest price. This sets precedents for the emergence of social, socioeconomic and socioenvironmental arrangements within a context of local development.

In order to analyze one of the 5568 Brazilian municipalities that can characterize the largest number of activities and learning in addition to having a larger field to discuss sustainable development and sustainability, Porto Velho, capital of the state of Rondônia, was chosen. With an estimated population of 494,013 inhabitants (IBGE, 2017) [11], it is the most populous municipality in the state, and the fourth most populous in the Northern Region. It stands out for being the Brazilian capital with the largest territorial area, extending over just over $34,000 \mathrm{~km}^{2}$. It is the only state capital that borders another country, Bolivia (Prefeitura Municipal, 2019) [12].

NSFP-PNAE resources for the municipality of Porto Velho are sent in two ways in the municipality, managed differently by the Municipal Education Secretariat (SEMED) and the State Education Secretariat (SEDUC). Each secretariat has specific decrees and laws in addition to Law 11,947 [5], and the activities of these two systems influence the organizational dynamics of small rural producers and communities around schools.

Thus, in this article, the objective is to analyze how the evolution of Law No. 11,947 [5] promotes expansive learning in the Brazilian National School Feeding Program (NSFPPNAE). For this analysis, the Theory of Expansive Learning (TEL) proposed by Engeström and Sannino (2010) was used [13]. For initial characterization of the main social actors involved in the Activity System, the Cultural-Historical Activity Theory (CHAT) was used in the view of Engeström $(2001 ; 2015)[14,15]$.

TEL was instrumental in describing the process of creating laws and regulations both within the scope of the management of SEDUC and SEMED, depicting the context prior to Law No. 11,947 [5], its implementation process and the period of consolidation until 2020. It was possible to report the historical periods with the seven phases of expansive learning: questioning (1), analyses (2), construction of a model to solve the problem (3), examination and test phase of the new proposal to be implemented (4), resisting and implementing (5), reflection on the new model in the process as a whole (6) and, after stabilization, the consolidation of a new practice (7).

The practical contributions of this article bring attention to the importance of the guidelines of Law No. 11,947 [5] at a national level, with openings for insertions and local adaptations mainly at the municipal level. Some effects of the general policy were highlighted, such as food, nutrition, cognitive and social aspects for students, besides the productive aspect, benefiting family farmers, some cooperatives and small food processing industries in rural areas through the organization of their food chains. An articulation was noted between a balanced diet and the preparation of a menu by nutritionists that prioritize healthy food products from family farming in the municipality. This means making the global connection between the emergent world discussion to advance in societal needs satisfaction and local development, in a consumption-production logic.

The article is organized in six sections. After this introduction, the empirical framework, with the description of the operation of PNAE and its historical process and the theoretical framework, characterized by the Theory of Expansive Learning (TEL) are introduced in Section 2, and the methodology is specified in Section 3. Qualitative results are described in Section 4 and further discussed in Section 5 and the conclusions are presented in Section 6. 


\section{Context of PNAE at National Level}

The construction and operation of PNAE in its current form was the result of several initiatives over the years. According to Peixinho (2013, p. 910) [16], the program had its origins in the Social Security Food Service (SAPS), founded in August 1940.

Provisional Measure 2178-36 [17] of 24 August 2001, established that 70\% of the resources transferred by the federal government would be applied exclusively to basic products and respect for regional eating habits and the municipality's agricultural vocation, fostering the development of the local economy. It also instituted, in each Brazilian municipality, the School Feeding Council (CAE) as a deliberative, supervisory and advisory body for the execution of the program.

Another important form of articulation between the FNDE and the executing units are the Collaborating Centers for School Feeding and Nutrition (CECANE). The CECANEs were established by the publication of Ordinance No. 1010/2006 [18] and Resolution CD/FNDE No. 38/2009 [19]. They are the result of a partnership started in 2007 between FNDE and the Federal Institutions of Higher Education. There are currently sixteen centers receiving FNDE funding throughout Brazil (Das Neves, 2018, p. 12) [20].

Law No. 11,947 [5] of 16 June 2009, was the result of an intersectoral process in the Federal Government and the participation of civil society through the National Council for Food and Nutritional Security (CONSEA) (Peixinho, 2013, p. 913) [16], in addition to the union of mobilization efforts such as the Grito da Terra Brasil. The trade union movement organized by the National Confederation of Rural Workers Farmers and Farmers Family (CONTAG) and Federations of Rural Workers Farmers and Farmers Family (FETAGs) in the period between 13 and 27 of May 2009, through 52 hearings involving more than 30 government agencies, 14 ministers and several executive secretaries, resulted in Provisional Measure 455/09 (MP 455/09) approved by the Federal Senate. This Provisional Measure determined that at least $30 \%$ of the purchase of food for school meals was from family farmers (Broch, 2009) [21].

This Law universalized the PNAE for all basic education, from early childhood education to high school, in addition to young people and adults. It defends food and nutrition education as a priority, thus strengthening the community's participation in social control of the actions developed by the States, FD and Municipalities. It provides support for sustainable development, encouraging the purchase of diversified, locally produced foodstuff, respecting seasonality, culture and food traditions in addition to prioritizing organic and/or ecological foods in school meals menus (Peixinho, 2013, p. 913) [16].

In order to develop inter-ministerial actions, Article 14 of Law No. 11,947 [5] of 2009 created the Management Committee, formed by representatives of the Federal Government through Ordinance No. 450 of 2010; and the Consultative Group with the participation of civil society representatives, in addition to representatives of the National Council of State Secretaries of Education (CONSED) and the National Union of Municipal Education Directors (UNDIME), with the purpose of advising the Management Committee. This Law established a new composition for the School Meals Councils (CAE), contemplating more representatives of entities of teachers, students or workers in the area of education, indicated by the respective class bodies. It also expanded the participation of representatives of organized civil entities, excluding the participation of representatives of the Legislative (Peixinho, 2013, p. 913) [16].

FNDE Resolution No. 26 [6] of 17 June 2013, corroborated Law No. 11,947 [5], clearing doubts about who could meet the demand for school meals. This Resolution established that, in addition to the Declaration of Aptitude for PRONAF (DAP), to be considered a family farmer, the individual must practice activities in rural areas, have an area of up to four fiscal modules, family labor, family income linked to the establishment and management of the establishment or enterprise by the family itself. Foresters, aquaculturists, extractivists, fishermen, indigenous people, quilombolas and agrarian reform settlers are also considered as family farmers (FNDE, 2019) [2]. 
On 3 April 2015, Resolution CD/FNDE No. 4 [7] changed the wording of articles 25 to 32 of Resolution FNDE No. 26 [6], which dealt with the acquisition of foodstuff from family farming and rural family entrepreneurs or their organizations. The Resolution published in 2015 modified the way in which the criteria for selection and classification of sales projects were applied; it also established what are formal and informal groups of agrarian reform settlers, traditional indigenous communities and quilombolas, and tie-breaking criteria; and defined the places where the notices of public calls should be published; included the document for qualification of the sales projects of the formal groups; established the prices of products to be purchased from family farming, which are those published in the public call; defined the individual sales limit for the family farmer in marketing to the PNAE by executing entity; established new rules to control the individual sales limit of family farmers; and defined models for public call notice, sales project price surveys and contracts (FNDE, 2019) [2].

On 8 May 2020, FNDE Resolution No. 6 [8] was approved, bringing news and standardization of measures that had already been adopted by some executing units. The Resolution provides guidelines for the executing units that chose to purchase meals by outsourcing services; establishes the public bidding, in the form of auction, in electronic form, pursuant to Law 10,520 [22], of 17 July 2002 and Decree No. 10,024 [23], of 20 September 2019; and introduces the PNAE Card, which will be a debit card from a current account in which the FNDE will open for the movement of Program resources.

It is noteworthy that due to the Coronavirus Pandemic, even before Resolution No. 6 [8], Law No. 13,987 [24] was ratified on 7 April, which amended Law No. 11,947 [5], to authorize, on an exceptional basis, during the suspension period of classes, the distribution of foodstuff acquired with PNAE resources to those responsible for students in public basic education schools. On 9 April, the FNDE instituted Resolution No. 2 [25], which regulated the distribution of foodstuff at the discretion of the local government.

As described, there were several events that triggered various knowledge among PNAE participants; knowledge that is not visible through numerical reports available to the population for consultation. The numbers achieved are the result of a mutual effort to implement the program, and it is precisely this construction of knowledge that this article highlights. To achieve this end, it was necessary to resort to CHAT (Engeström, 2001; 2009; 2015) $[14,15,26]$ and the Theory of Expansive Learning (Engeström and Sannino, 2010) [13].

Currently, the PNAE assists students from all basic education (early childhood education, elementary school, high school and youth and adult education) enrolled in public schools, philanthropic and community entities (agreements with the government). The federal government transfers 10 monthly payments to the states and municipalities and federal schools to cover 200 school days, according to the number of students enrolled (FNDE/PNAE, 2019) [1]. Different values are standardized and fixed according to the levels and modalities of teaching.

From an operational point of view, the Federal Government participates in the PNAE through the FNDE, which is responsible for defining the rules of the program. The executing entities are the education departments of the states, federal district and municipalities, and also include federal schools. Executing units are characterized by being a civil society with legal personality of private law, linked to the school, not for profit, which can be created by the initiative of the school, the community or both (FNDE, 2019) [2].

The School Meals Council (CAE) is responsible for monitoring the purchase of products, the quality of the food offered to students, the hygienic and sanitary conditions in which food is stored, prepared and served, distribution and consumption, as well as the task of evaluating the accounts of the executing entities (FNDE, 2019) [2].

The Federal Court of Accounts (TCU) and the Ministry of Transparency, Inspection and Comptroller General (MTFC) of the Union are federal government bodies that also oversee the program. The Federal Public Prosecutor, along with the FNDE, receives and investigates allegations of program mismanagement. The Departments of Health and Agriculture of the States, Federal District and Municipalities can collaborate with the PNAE 
through sanitary inspections, by attesting the quality of the products used in the food offered and by articulating the production of family farming. The CAE is responsible for inspections in schools and education departments. (FNDE, 2019) [2].

\section{Cultural-Historical Activity Theory and Theory of Expansive Learning}

The Cultural-Historical Activity Theory-CHAT, or Activity Theory, is the result of formative interventions based on two epistemological principles, the principle of double stimulation and the rise from the abstract to the concrete (Sannino, 2011) [27]. The first was formulated and implemented by Vygotsky, while the second derives from the works of Hegel and Marx, being incorporated into the activity theory by Lyenkov, which was systematically implemented as the basis for Davydov's theory of learning and instruction (Engeström, 2015) [15].

There are three generations in the evolution of the Cultural-Historical activity theory (Engeström, 2015) [15]. The first generation, centered on Vygotsky, created the idea of mediation. The limitation of the first generation was that the unit of analysis remained individually focused. This was overcome by the second generation, led and inspired by the work of Leontiev. Leontiev (1981, pp. 210-213) [28] showed how the historically evolving division of labor brought about the crucial differentiation between individual action and collective activity. However, it never graphically expanded Vygotsky's original model into a model of a collective system of activity.

The relationship between object-oriented production and communicative exchange between people remained somewhat obscure in Leontiev's work. Since the 1970s, the tradition has been taken up and contextualized by researchers in the West. New domains of activity, including work, were opened up for concrete research. A variety of applications of the activity theory began to emerge. The idea of internal contradictions as the driving force of change and development in activity systems, strongly conceptualized by Ilyenkov, began to gain due status as a guiding principle of theoretical work and empirical research (Engeström, 2015) [15].

However, Michael Cole (Cole, 1996; Griffin; Cole, 1984) [29,30] was one of the first to point out the profound insensitivity of second-generation activity theory in relation to cultural diversity. As activity theory became international, issues of diversity and dialogue between different traditions or perspectives became increasingly serious challenges. It is these challenges that the third generation of the activity theory began to tackle (Engeström, 2015) [15].

The third generation of activity theory developed conceptual tools to understand networks of activity systems in interaction, dialogue and multiple perspectives and voices. Engeström (2015) [15] first expanded Leontiev's theory of activity, keeping the Activity System as the basic unit of analysis, but incorporated sociocultural artifacts that should mediate the interaction between subject and object, such as rules, division of work and community.

After consolidating his model, Engeström (2015) [15] expanded it to include at least two systems of interacting activities. The systems, in turn, interact with each other and show confrontations, which often generate opportunities for transformation (Engeström, 2001) [14].

For Engeström (2001) [14], the activity theory can be summarized in five principles. The first principle is a collective Activity System as a primary unit of analysis. The activity system is mediated by artifacts and is object oriented, relating to other activity systems. In this case, individual and group actions directed towards goals, as well as automatic operations, are relatively independent but are subordinate to units of analysis, eventually understandable only when interpreted against the background of entire systems of activities.

The second principle is the multiple voice of Activity Systems. For the author, an activity system is considered a community with multiple points of view, traditions and interests. The division of labor generates different positions among the participants, who 
carry their own stories, which in turn are reflected in their artifacts, rules and conventions (Engeström, 2001) [14].

The third principle is Historicity. In this case, it is observed that activity systems change over long periods of time. Their potential problems can only be understood in comparison to their own story. History itself needs to be studied as the local history of the activity and its objects, taking into account how the history of ideas and theoretical tools shaped the activity (Engeström, 2001) [14].

The fourth principle is the central role of contradictions as sources of change and development. Contradictions cannot be considered synonymous with problems or conflicts. They are, historically, an accumulation of structural tensions within and between activity systems. When the activity system adopts a new external element, it often leads to a contradiction that is aggravated by some elements (the rules or the division of labor). These contradictions, in turn, generate disturbances and conflicts, which can be reinterpreted as innovative attempts to change the activity (Engeström, 2001) [14].

The fifth principle concerns the possibility of expansive transformations. Activity systems experience long cycles of transformation. As the contradictions of an activity system are aggravated, some individuals begin to question and deviate from their established norms and rules. This, eventually, can turn into a collaborative vision and a deliberate effort for collective change (Engeström, 2001) [14].

Within the Activity System, an expansive transformation can take place, which results from situations in which the object and motive of the activity are re-conceptualized to encompass a broader horizon of possibilities than that of the previous mode of activity. A complete cycle of expansive transformation can be understood as a collective journey through the activity's zone of proximal development. It is the distance between the individuals' present everyday actions and the historically new form of social activity that can be collectively generated as a solution to the double bond potentially incorporated in everyday actions (Engeström, 2001) [14].

According to Engeström (2001) [14], the five principles presented must be crosstabulated with the four essential questions of the theory: (1) Who are the learning subjects, how are they defined and located? (2) Why do they learn, what makes them make the effort? (3) What do they learn, what are the learning contents and outcomes? (4) How do they learn, what are the main learning actions or processes? From this, a matrix is obtained that serves as a structure to summarize the answers offered by the Theory of Expansive Learning.

In addition to supporting the empirical development of CHAT, it serves as a basis for the development of the Theory of Expansive Learning, as the questions used will serve to justify the seven phases of its cycle. For Engeström and Sannino (2010) [13] the expansive learning process must be understood as the construction and resolution of contradictions in successive evolution. All the typical-ideal expansion cycles can be schematically represented by seven phases: the questioning (1), the analysis (2), the construction of a model to solve the problem (3), the phase of examination and testing of the new proposal to be implemented (4), overcoming resistance and implementation (5), reflection on the new model in the process as a whole (6) and, after stabilization, the consolidation of a new practice (7).

\section{Methodology and Methodological Procedures}

This research is qualitative (Sampieri; Collado; Lucio, 2006; Merriam, 2002) [31,32] and performed in abductive reasoning (Charreire and Durieux, 2003; Cruz, 2007, p. 53) [33,34]. A case study was used as the primary data collection strategy, besides secondary data (Yin, 2018) [35]. Regarding the research design, it is descriptive research (Aaker; Kumar; Day, 2001; Triviños, 2007; Sandelowski, 2000) [36-38].

A single and incorporated case study was chosen, as it has sub-units of analysis that can be incorporated in the same context, adding significant opportunities for extensive analysis and improving ideas about the single case (Yin, 2018) [35]. The main unit is the execution of the PNAE as a whole within the municipality of Porto Velho, which in turn is 
divided into two units of analysis: the municipal execution (SEMED) and the state execution (SEDUC). Between these two units of analysis there are intermediate units: municipal and state schools, union leaders and family farmers, since union leaders and farmers participate in the two main units of analysis within the same context. Therefore, this justifies the choice of the incorporated single case study design.

First, visits were made to SEMED and SEDUC to create a prior mapping of which would be the main actors involved in the historical process related to the PNAE in the municipality of Porto Velho. Through the study of specific legislation and consultation with nutritionists coordinating the program in the state of Rondônia and in the municipality of Porto Velho, key actors were identified, distributed as shown in Table 1. Among these actors, employees of the departments of education and agriculture, members of school food councils, union leaders, three cooperatives of farmers, a fish processing industry and principals of three schools stand out. In total, there were 21 respondents.

Table 1. Characterization of respondents.

\begin{tabular}{|c|c|c|}
\hline Institution & Respondent Code & Respondent Characteristics \\
\hline SEDUC State Department of Education & ESED01 & 1. Nutritionist responsible for the PNAE \\
\hline SAE-School Feeding Department & ESED02 & 2. Administrative technician \\
\hline $\begin{array}{c}\text { SEAGRI—State Department of } \\
\text { Agriculture }\end{array}$ & ESEA02 & 3. Administrative technician \\
\hline $\begin{array}{c}\text { CAERO—Rondônia State School Feeding } \\
\text { Council }\end{array}$ & ECAE01 & 4. Volunteer member \\
\hline $\begin{array}{c}\text { SEMED_Municipal Department of } \\
\text { Education }\end{array}$ & ESEME01 & $\begin{array}{l}\text { 5. Nutritionist responsible for contact } \\
\text { with farmers }\end{array}$ \\
\hline DIALE—School Food Division & ESEME02 & 6. Nutritionist for operational activities \\
\hline & ESEME03 & 7. Financial administrative \\
\hline CAEM-Muni. School Feeding Council & ECAEM01 & 8. Volunteer secretary of the council \\
\hline $\begin{array}{c}\text { CONTAG/ Porto Velho Rural Workers } \\
\text { Union }\end{array}$ & ECON01 & 9. Union president \\
\hline $\begin{array}{l}\text { FETAGRO_Federation of Rural Workers } \\
\text { and Family Farmers of Rondônia }\end{array}$ & EFF01 & 10. Treasurer \\
\hline PROGRESSO fish processing industry & ЕРP01 & 11. Responsible veterinarian \\
\hline COOPAGROVERDE & ECGREEN01 & 12. President \\
\hline COOPAFARO & ECFARO01 & 13. President \\
\hline $\begin{array}{l}\text { RECA-Agricultural and Forestry } \\
\text { Cooperative }\end{array}$ & EREC01 & $\begin{array}{l}\text { 14. Cooperative representative in the } \\
\text { capital Porto Velho }\end{array}$ \\
\hline $\begin{array}{l}\text { Association of family farmers in the } \\
\text { Sector Chacareiro neighborhood }\end{array}$ & ESCH03 & $\begin{array}{l}\text { 15. Associate who attends the PNAE } \\
\text { individual modality }\end{array}$ \\
\hline $\begin{array}{l}\text { State Elementary School in the Central } \\
\text { Zone with } 450 \text { students }\end{array}$ & EEEFBN01 & 16. Principal \\
\hline $\begin{array}{l}\text { District of Nova California State } \\
\text { Elementary and Secondary School with } \\
600 \text { students }\end{array}$ & EEEFMB01 & 17. Principal \\
\hline $\begin{array}{l}\text { Rural Municipal School of Elementary } \\
\text { Education with } 47 \text { students }\end{array}$ & EMEFRSA01 & 18. Principal \\
\hline Municipal Elementary School in the & EMEFAFS01 & 19. Principal \\
\hline Central Zone with 800 students & EMEFAFS02 & 20. Principal Assistant \\
\hline $\begin{array}{l}\text { Municipal Elementary School in the West } \\
\text { Zone with } 250 \text { students }\end{array}$ & EMEFPC01 & 21. Principal \\
\hline
\end{tabular}


It is important to note that the interviews were held in four periods: May and October 2019, continued between January and March 2020 and finally, due to the Coronavirus Pandemic, it was decided to return to the field between May and September 2020 to record changes in the execution of the PNAE. Therefore, the characteristics exposed so far denote research of an abductive nature.

The interviews were semi-structured; although the interviewee was free to deepen the report, some points were determined according to the theoretical support to achieve the objectives of this research. In order to maintain the secrecy and confidentiality of data, respondents were not identified. Furthermore, it is important to emphasize that all respondents signed the Authorization Term for Academic Research and the Free Consent Term. Minors did not participate in the survey, either through interviews, observation or photographic records.

Non-participant observation was used, a technique with less involvement of the researcher in the field, given that the interest is in the observation and not in action (Flick, 2009) [39]. Thus, the interviews, as well as the observation process, were documented through the use of field notes (Lofland, 1974; Lofland; Lofland, 1995) [40,41]. In addition to interviews and observations, 83 documents were analyzed, including internal documents, legislation and regulations.

In the context of this research, according to Bardin (2011) [42], the interviews were transcribed and were re-read; codes were established for the formulation of analysis categories through the theoretical framework, in this case the CHAT and Theory of Expansive Learning.

Afterwards, the material was cut in registration units, in this case, sentences and paragraphs, with the same semantic content as the theories discussed. After moving from raw data to organized data, the categories were formulated. The formulation of these categories followed the principles of mutual exclusion, homogeneity, relevance in the transmitted message, fertility and objectivity. There was grouping of registration units into common categories, then progressive grouping of categories and, finally, inference and interpretation, based on the theoretical framework.

\section{Results}

This session characterizes the main actors in Activity Systems and analyzes the evolution of the application of Law No. 11,947 in the municipality of Porto Velho using the expansive learning cycle proposed by Engeström and Sannino (2010) [13].

\subsection{Activity System in the Municipality of Porto Velho}

Porto Velho is a Brazilian municipality and capital of the state of Rondônia. It is located besides the Madeira River in the Northern Region of Brazil. It was founded by the American company Madeira Mamoré Railway Company on 4 July 1907. On 2 October 1914, it was legally created as a municipality in Amazonas state, and in 1943 it became the capital of the Federal Territory of Guaporé (Prefeitura Municipal, 2019) [12].

With a population of 494,013 inhabitants (IBGE, 2017) [11], it is the most populous municipality in the state of Rondônia and the fourth most populous in the Northern Region. It is the Brazilian capital with the largest territorial area, extending over just over $34,000 \mathrm{~km}^{2}$. It is the only state capital that borders another country, Bolivia (Prefeitura Municipal, 2019) [12]. In economic terms, the city has a Gross Domestic Product (GDP) per capita of BRL 28,836.46 (IBGE, 2017) [11].

Education departments are the most important social actors in the execution of Law No. 11,947 [5] in the municipality of Porto Velho. As previously mentioned, SEDUC and SEMED do not have shared management of schools; that is, each department is responsible for its group, in the case of state schools and municipal schools. Therefore, in order to better understand the CHAT of the municipality, it is necessary to analyze municipal and state managements separately. 
There is a department responsible for managing the activities related to PNAE, SEMED, the School Feeding Division (DIALE). DIALE is composed of 15 employees, with a manager responsible for the division, 5 nutritionists and 9 employees distributed in administrative functions. The department serves an average of 15 to 20 people daily, including principals, school teachers, suppliers and the community in general, with two service teams in two shifts, in the morning and in the afternoon (SEMED, 2019) [43].

The municipal education network in Porto Velho, according to the 2019 census of the National Education Development Fund (FNDE), has 50,210 students. These students are distributed in 144 school units, and are served by centralized, decentralized and private/agreeing school units. Centralized school units are understood as those that do not have a formed school council, and there are 15 schools in this modality in the municipality. The decentralized school units have formed a school council, being represented by 124 schools, while there are five private/agreeing school units (SEMED, 2019) [43].

Understanding this classification is important for the scope of the PNAE because it determines how the Department of Education will act. For example, at the centralized units, SEMED purchases foodstuff and distributes among them. In decentralized units, resources are made available to the school unit to purchase its own foodstuff. Private educational institutions, on the other hand, make an agreement with SEMED to receive only PNAE resources.

Regarding public calls, in decentralized management, each executing unit is responsible for its call. The buyer, in this case the school, and the supplier sign the contract that establishes the product delivery schedule, the payment date to family farmers and all other purchase and sale clauses. The start of delivery of products must meet the expected schedule and payments are made directly to farmers or their organizations. (SEMED, 2019) [43].

For the public call to take place, it is necessary to formulate a universal price list, which will serve all schools in the municipal education network. Until 2019, SEMED carried out price surveys to formulate the amount to be paid for family farming products, there were at least three surveys in the local or regional market. For organic or agroecological products, if there was no way to research the price, it was possible to add $30 \%$ more compared to conventional products. The formulation process has not changed, but as of 2020 this price survey would be performed by an employee of the Municipal Department of Agriculture (SEMAGRIC).

Farmers, to participate in the public call, need to present the sale project, which is made by the Entity for Technical Assistance and Rural Extension of the State of Rondônia (EMATER -RO), together with the documentation required by DIALE, and nutritionists will assess whether the producer is qualified or not. The Diale does not use a legal department to assist in the evaluation of suppliers' documentation, so the nutritionists end up playing this role. Basically, SEMED has autonomy to implement Law No. 11,947. Until 2019, the secretariat had a relationship with EMATER for issuing projects, school directors and direct contact with farmers.

The CAEM (Municipal Food Council) inspects both the PNAE and the Municipal School Feeding Program (PMAE). It is certainly a very important actor in the execution of the PNAE. There is CAERO (School Feeding Council of the State of Rondônia), but it works for state schools. The two pieces are not related.

According to the 2019 census of the National Education Development Fund (FNDE), there are 301 thousand students in state network of Rondônia, but 63,810, are allocated in the municipality of Porto Velho totaling 74 schools (FNDE, 2020) [44]. Like municipal schools, state schools that have a School Council receive funds directly from the FNDE, featuring decentralized management.

State schools are subject to SEDUC. Within the Secretariat there is the Program Management, which is responsible for planning, organizing and coordinating the administrative actions and activities concerning the programs and projects under its responsibility; guiding, monitoring and consolidating results in management reports; providing follow-up 
instruments; and monitoring the approvals of the rendering of accounts of the resources transferred from the programs carried out by the School Units of the State Public Network and the Regional Education Coordination (CREs). The Monitoring Sub-Management of the School Feeding Program is one of the units of this management, which is responsible for coordinating, planning, executing, supervising and controlling activities that ensure the quality standard of the food offered to the student clientele of the state education system (Rondônia, 2018) [45].

The SAE (School Feeding Department) has 11 employees, including 4 administrative technicians, 2 nutritionists, 4 commissioned employees (technical advisors trained in nutrition) and 1 intern. The sub-management has the support of the Nucleus of the National School Feeding Program, which is responsible for calculating and transferring the financial resources from the PNAE for the purchase, by schools, of food for school meals; and the Center for the State School Feeding Program, which is responsible for calculating and transferring financial resources from the State Treasury, intended to complement the school meals (Rondônia, 2018) [45].

SEDUC also has other bodies to carry out the public call. One of them is the State Superintendence of Procurement and Tenders (SUPEL), which receives documents from farmers. For the analysis of the Accreditation Documents, a Judging Committee is appointed by means of an Ordinance issued by the Secretary of State for Education, which will examine the documentation required for accreditation purposes regarding compliance with the conditions established.

Until 2019, SEDUC carried out its price research for the acquisition of family farming products, but it was agreed through the Technical Cooperation Term No. 9969789 between SEDUC and the State Agriculture Department (SEAGRI) that as of 2020, the price list would be created by SEAGRI based on the same methodology used in the state Food Acquisition Program (PAA).

Reinforcing the issue of standardization for the execution of the PNAE, there is an institution responsible for overseeing, deliberating and advising, the National School Feeding Program, and the state has the support of the Rondônia School Feeding Council (CAERO).

The farmers are an Activity System part of SEMED and SEDUC. In the municipality there are six cooperatives and individual farmers that serve the two secretariats. EMATER is another very important actor for the functioning of the Activity System; through its services, it contacts all farmers in the municipality. EMATER assesses whether the producer is able to receive the DAP, which permits small farmers to enter various public policies. These farmers, although they are part of family farming, have different profiles and interests, and organize themselves in different ways. These convergences and divergences give dynamism to the Activity System.

The unions also participate in this activity system of farmers, among them the Trade Union Movement of Rural Workers, which is a state representative of the National Confederation of Rural Workers Farmers and Farmers Family (CONTAG), and the Federation of Agricultural Workers in the State of Rondônia (FETAGRO).

After characterizing the main actors involved in the Activity System to comply with the requirement of Law No. 11,947 [5], the facts and events that triggered the execution of this law in the municipality of Porto Velho-RO were analyzed. Through the discussion of four questions: "Who learns?", "Why do they learn?", "What do they learn?" and "How do they learn?", expansive learning was described as it occurs.

\subsection{Expansive Learning to Comply with Law No. 11,947}

Expansive learning led to the consolidation of Law No. 11,947 [5], the result of an activity pattern oriented towards the execution of the PNAE. The formation of an expanded object corresponding to the new pattern of activity requires and produces distributed agency, questioning and breaking the constraints of the existing activity. The rise from the abstract, the law on paper, to the concrete, the execution of the law itself, is carried out 
through epistemic actions or specific learning. These actions, in turn, form an expansive cycle or spiral.

\subsubsection{Historical Facts between 1981 and 2002}

Rondônia was only consolidated as a state in 1979, formulating its public policies while the PNAE, in 1983, experimented with innovations such as decentralization, stateization with municipalization, in the states of Rio de Janeiro and São Paulo. In this proposal, state agencies, of education or planning, began to coordinate the program. They were in charge of its management and articulation with the city halls of the states, and the FAE was responsible for strengthening the state governments and passing on some attributions to them (Spinelli and Canesqui, 2002) [46].

In addition to these measures, in 1987, with State Decree No. 3290, the basic structure of the Support Fund for Small Rural Producers (FAPP) was established, whose purpose was to encourage the activities of small agricultural producers, members of cooperative, non-profit associations and informal groups. The Fund was chaired by members of the following entities: State Secretariat for Agriculture and Supply (SEAGRI); Rondônia State Bank (BERON); Technical Assistance and Rural Extension Company (EMATER); and Organization of Cooperatives of the State of Rondônia (OCER).

Six years later, the municipal public schools of Porto Velho instituted School Councils constituted by the management and members of the school community through Municipal Decree No. 5251 of 10 November 1993 [47]. Therefore, in July 1994, when Law No. 8913 [48] was enacted, these schools entered the process of municipalizing school feeding, decentralizing the purchase of these foods even more, as the purchase committees, formed by employees and students' parents, started to do this.

In the same period, state schools were still centralized; that is, the funds were sent to SEDUC, which made purchases and distributed supplies throughout the state. However, through State Decree No. 6681 of 26 January 1995 [49], a special working group was set up in the Secretariat to establish criteria for the creation and functioning of Regional Police Stations and Regional Education Centers, which had already instituted Councils aiming at decentralization.

State Decree No. 6901, of 22 June 1995 [50], was one of the first measures of decentralization in Rondônia. A special working group was constituted within the scope of the State Secretariat for Education (SEDUC), which promoted the technical coordination, execution, monitoring and evaluation of the actions of the Agreement 2744/FAE/SEDUC, signed between the State and the Union, for the fiscal year of 1995, aiming at proof of a counterpart of $30 \%$ of the PNAE.

On 9 July 1997, by means of Complementary Law No. 177 [51], the Rondônia School Meals Council (CAERO) was created, with the purpose of advising the Education Secretariat in the execution of the PNAE. At the time, their assignments were: to supervise and control the application of resources destined to school meals; promote the preparation of menus and school feeding programs, respecting the population's eating habits and the state's agricultural vocation, and giving preference to natural products; guide the acquisition of inputs for school feeding programs, giving priority to products from the region; liaise with government agencies or services at the state and federal levels and with other public or private administration bodies, in order to obtain collaboration or technical assistance for the improvement of school meals distributed in state public schools; and establish criteria for the distribution of school meals in state public establishments.

According to the interviewee ESEA02, in 1997 CAERO had 28 servants who worked with the purpose of orientation to get everything ready and systematized to ensure continuity. Among the counselors there were two nutritionists who visited and lectured at schools across the state, along with the accounting and legal guidance team. These actions that were taking place in the state of Rondônia converged on what was happening at the federal level. On 14 December 1998, Provisional Measure No. 1784 [52] authorized the direct transfer of amounts to school boards, without the need to sign agreements, allowing for greater 
flexibility in the process. During this period, the program-already under the command of the FNDE_-instituted, on 24 August 2001, Provisional Measure No. 2178-36 [17], which established that $70 \%$ of the funds transferred by the federal government were to be applied exclusively to basic products respecting regional eating habits and the municipality's agricultural vocation, fostering the development of the local economy. It is noteworthy that it also instituted, in each Brazilian municipality, the School Feeding Council (CAE) as a deliberative, supervisory and advisory body for the execution of the Program.

\subsubsection{Organization and Institution of Law No. 11,947 between 2003 and 2012}

After the presidential elections, within the scope of the Zero Hunger Program, the PAA was instituted by article 19 of Law No. 10,696, of 2 July 2003 [53]. It was in Rondônia and Acre, where the program was implemented in the same year, soon after initial issues of operationalization of the modalities were resolved, with the development of several actions linked to the program (Valnier and Ricci, 2013) [54].

In Rondônia more specifically, the implementation of the PAA was the result of a project of the Rural Workers Union of the Municipality of Porto Velho, encouraged by the then secretary of education of the municipality Roberto Sobrinho. Interviewee ECON01 reports how the process of operationalization of the PAA was, which later guided procedures within the scope of the PNAE:

"It's not from 2003, it's from 1995 of Fernando Henrique Cardoso government... When it was 2003 we revived this. The first PAA was made here in Porto Velho. The first PAA when it was shelved in 95 during the Fernando Henrique Cardoso government... when Lula arrived, he rescued it there, but it was kind of stuck in the drawer who discovered this was Roberto Sobrinho there in Brasília. He wasn't a candidate for anything at the time. He found out and came and called me, "there's a law like that... does it interest us here in the city? I said "I'm interested" "How are we going to do it?" "I'm going to call the association". 38 associations came, from these 38 associations we selected some that had document... we selected 8 , of these 8 , just 5 were approved. Of these 5 we did the project for Brasília, the PAA resource it was from Ministry of Social Development (MDS). When we started the PAA, to spread the PAA in Brazil, we took the project to Brasília. I went to show Lula, our first resource in Porto Velho, was of 622 thousand Reais. It was very sudden, we had to finish by 25 December ... a SEMED server helped a lot." Interviewee ECON01

The first donations from the PAA were destined for military schools and community entities such as the Rosetta Family House, the Rondônia Association of Parents and Friends of Drug Addicts (APATOX), the Cultural and Educational Spiritist Institute André Luiz (ICEAL), Spiritist Center Brothers Jacob and other community schools, which were maintained by the community. According to interviewee ECON01, the students' food was very precarious, but after the food donations, it was noted that school performance improved. It was from this that the idea of the "Sabor do Campo" project emerged, conceived by the same employee of SEMED, who had also helped in the formulation of the project for the PAA resource in 2003.

"Sabor do Campo" (Taste of the Field) was a project that was part of the "Zero Hunger" program, but at the municipal level. This project was developed by the Municipal Department of Education (SEMED), through the School Feeding Division (DIALE). It was launched on 30 May 2007, with the aim of including 45 products from family farming, such as banana, açaí, cupuaçu and tapioca flour, in the school menu. "Sabor do Campo" gave more autonomy to schools, which started to decide which products to buy, when and from whom to buy, with due monitoring by school councils and parents' associations. The purchase could only be made from members of unions and cooperatives. There was an incentive to associativism and this was extremely important for the producer's growth. With direct purchase, it was possible to reduce costs, as there are in the middlemen (Prefeitura Municipal, 2019) [55]. 
Between 2005 and 2009 some courses were offered to members of RECA, a local cooperative of Nova California/RO. It was a great opportunity for local farmers to acquire knowledge because there is a cleavage in Brazil federal governance about the orientations of the Ministry of Agrarian Development (MDA) together with the Ministry of Social Development (MDS). The interviewee EREC01 talks about the courses he took:

"At the time of the Ministry of Citizenship, I took a basic technician's course in Manaus, Santa Maria, in Rio Grande do Sul, Brasília, at family farming fairs. They sent me to Brasília, I know it was because I was one of the pioneers to participate in the MDA courses, I had everything paid to participate in the course to be the creator. We were going to be the base of the Citizenship territory, mainly in the Madeira Mamoré territory, which would be here in Porto Velho, Guajará-Mirim to Itapuã, in the 5 municipalities." Interviewee EREC01

In 2007, SEDUC was already organized to meet changes, through Ordinance No. 0323/07-GAB/SEDUC [56] issued on 18 January, established the Commission for Registration of Companies Supplying School Meal Products, to schools in the Network State Public, within the scope of the Municipalities of Porto Velho, Candeias do Jamari and Itapuã do Oeste-RO. In the following years, this commission evolved into a department known as the School Feeding Program (PALE).

Union mobilizations known as Grito da Terra Brasil, organized by CONTAG and FETAGs, promoted great advances for family farming since 1995. The 2009 edition, from 13 to 27 May, counted on 52 hearings, which involved more than 30 government agencies, 14 ministers and several executive secretaries, and the Federal-Senate-approved Provisional Measure 455/09 (MP 455/09). This document determined that the purchase of food for school meals would be at least 30\% from family farmers (Broch, 2009) [21]. The following testimonial shows how union organizations organize themselves:

"It was via Brasília, right ... we used to write our own Grito da Terra, Grito da Terra Nacional, it was a national publication. We discussed costs with the federal government, with ministers, all this demand for public policies aimed to family farming. The era of food acquisition, agrarian reform and settlements, health, education, rural housing, there are several items that we discussed within the National Grito. There were 10 thousand, 15 thousand rural workers in Brasília. A committee, we formed 15 days to 30 days before. I participated until 2013. There we first discussed with the minister the demand. Then they said what could be met, what could not be met. Sometimes it was very favorable, sometimes with victories, sometimes not so positive, right." Interviewee ECON01

On 16 June 2009, Law No. 11,947 [5] was published, enabling the public manager to waive the bidding process through another instrument, the Public Call, regulated by FNDE through Resolution No. 38 of 16 July 2009 [19]. Thus, the obligation to acquire at least $30 \%$ of the financial resources transferred by the PNAE in foodstuffs directly from family farming was defined.

On 25 February 2010, at the State School Major Guapindaia in Porto Velho, SEDUC through the School Feeding Project, conducted a meeting with managers on implementation of school meals. The objectives were to provide guidance on the menus, which would be differentiated by age group, according to the FNDE resolution, in addition to informing the operational norms for the participation of farmers and rural entrepreneurs in the process of providing food for school meals. The lectures were given by a contracted nutritionist, by the legal advisor and by the president of the Commission for Registration of Companies Supplying Merenda Escolar products. There was collaboration from CAERO, EMATER and SEAGRI.

According to the interviewee ESED02, in 2009, SEDUC had started to take the first steps to adapt to the changes. However, in 2010, according to his report, there was a very big problem regarding the legalization of documentation. It is believed that there was a lack of faster means of communication, as the speed was not the same as it currently is due 
to applications and social networks. Therefore, there were places that could not obtain this supply from family farming, "not because the municipality, the locality did not produce, but because of the lack of legal documentation".

In parallel, in 2010, SEMED used Sabor do Campo, which was a project, not a real program. There were six farmers who served the schools. In order to implement Law No. 11,947 [5], a nutritionist, already experienced in the implementation of the standards, was transferred from Machadinho d'Oeste to be technically responsible (TR) in Porto Velho. The interviewee ESEME01 tells how the first registration was:

"Then in 2011 we went from 6 to 182 family farmers, counting on the members, because the cooperative demanded the largest number of members. We had a very high demand, because we went to television when I went to local channel. Those who watched the TV program were participating. We had the corridor full of farmers." Interviewee ESEME01

Nutritionist ESEME01 says that in 2011, when she arrived at SEMED, she faced a difficulty that was the inexistence of a regulated inspection service. Although it was the responsibility of the Municipal Department of Agriculture, there was no responsible department. She participated in a task force together with the secretary at the time, who organized the legal part to send to the chamber. After the formalities, the veterinarians were hired and she went to give training at SEMAGRIC so that they would understand that the aim of the municipal inspection service was to serve the Municipal Education Department. Interviewee EPP01, at the time one of the veterinarians, recounts how this initial learning was:

"ESEME01 is good people and she has been there since the beginning. At the time ESEME01 was from SEMED and I was from SEMAGRIC, so when there were meetings, it was a clash all the time. There was dialogue and it was very good! Things have developed in our time, advanced a lot." Interviewee EEPP01

As the implementation of the norms progressed, new laws emerged to complement Law No. 11,947 [5]. This was the case of Municipal Decree No. 12,563 of 26 March 2012 [57], which replaced Municipal Decree No. 5251 of 10 November 1993 [47]. Its text reports, in Article 3, the main attributions of the School Council. In its article 4 it clarifies the figure of the principal as a natural member and, in his impediment, the figure of the principal's assistant appointed by him. In Decree No. 12,563/12 [57], representation is divided equally between employees and parents and students, both segments with $50 \%$ (fifty percent) of representation, and the election of these members is made by a General Assembly, by acclamation or secret ballot.

The issue of nutritionists at SEDUC was a little more delicate. In 2012, with the enactment of Complementary Law No. 680/2012 [58], the position of nutritionist was created in the career structure of professionals in the state education system, although there were five candidates approved in the competition, at the time, they had not taken office (TCU, 2017). So, the Secretariat changed the position of RT (responsible technician) nutritionist for nutritionists who were deviated from their function, that is, teachers with public exams who took a course in nutrition.

After the period of adaptations for the operationalization of Law No. 11,947 [5], the first difficulties were found through inspections carried out by FNDE, CAEM, CAERO, TCU, among other regulatory bodies. New challenges arose, but there were also innovations.

\subsubsection{Consolidation and Inspections in the Period between 2013 and 2020}

On 17 June 2013, with FNDE Resolution No. 26 [6], there was a clarification on how the $30 \%$ of the resource used in the purchase of foodstuff directly in Family Farming is to occur. The profile of the farmer for the Program was better detailed, strengthening sustainable development in the municipalities. To verify compliance with this resolution, there was an FNDE audit of SEMED in the same year. According to counselor ECAEM01, the difficulty of obtaining documentation from farmers was the agenda of a meeting between the FNDE, 
CAEM, DIALE and the Secretary of Education committee. It was discussed that there were many farmers in the municipality, but they only owned the land, without a definitive document. Therefore, it was justified that the number of suppliers was not greater because documentation within the established parameters was required.

Interviewee ESEME01 reports that even in 2013 she found expired foodstuff in schools. At the beginning, the group of nutritionists did not have much autonomy, so a meeting was held with the mayor at the time and a consensus was reached where expired food found, in addition to being incinerated, should be replaced by the municipality with the school manager's own resources, for this situation characterizes misuse of public money, and some principals were punished. Counselor ECAEM01 confirms the fact through the following fragment:

"There have already been situations of a lot of loss of meals, at a certain time there was an audit by the FNDE and they suggested that it is a loss for the student, it is a loss for the resource. When you arrive at school you have $50 \mathrm{~kg}$ of expired beans ready to go to waste to be incinerated ... what are we going to do? The principal will be held responsible. That's where you practically no longer find expired products." Interviewee ECAEM01

On 28 May 2014, Law No. 12,982 [59] amended article 12 of Law No. 11,947 [5], to determine the provision of adequate school meals to students with a specific state or health condition. In the same year, with state decree No. 19,115 of 25 August [60], regulations were established for the transfer of PNAE financial resources to the executing units of schools.

The year of 2015 was very important for the state management in relation to the PNAE due to the implementation of some Regional Education Coordination (CREs) through the complementary state law $\mathrm{n}^{\circ} 829$ [61] on 15 July and by the state law No. 3753 [62] on 30 December, which instituted the PEALE (State School Feeding Program). The creation of CREs was important, as these units act as administrative bodies subordinate to SEDUC, responsible for the regional management of schools. Within the scope of the PNAE, the CREs register family farming producers that can participate in the program, carry out public calls, price quotations, in addition to having a nutritionist who coordinates the processes related to the program in the region, while PEALE guarantees the counterpart of PNAE in school meals.

The first half of 2016 was marked by inspections that made notes to the secretariats. From 7 to the 25 of March, the Ministry of Transparency, Inspection and Control audited SEDUC and during the 13 to the 24 of June, FNDE inspected SEMED.

There were positive value changes with Municipal Decree No. 14.339 of 9 November, which adjusted the per capita student/month value for the transfer of financial resources from the Municipal School Feeding Program (PMAE) to schools in the municipal public education network. In addition to the PNAE, the PMAE obtained an increase in transfers to schools from BRL 0.15 to 0.30 student/day (Prefeitura Municipal, 2019) [63]. Therefore, SEMED guaranteed a school lunch menu reinforced with the purchase of more products, including those from family farming. This complementary program, in addition to improving the feeding of students, offered more competitive prices for farmers.

In that same year, on 22 September, SEDUC held a Public Tender governed by Notice No. 237/GCP/SEGEP, which included five places for nutritionists. In 2017, through Decree No. 22.048, of 28 June 2017, the call was made to take office. Nutritionist RT was chosen for the execution of the PNAE in Porto Velho.

Following the changes that had been taking place in 2017, through State Decree No. 22,179 of 8 August [64], fish from the region were included, such as: Tambaqui, Pirarucu and Pintado in the form of fillet and pulp, in the school meal menu of public educational institutions in the state. SEDUC is responsible for transferring the value to the executing unit (school council), in a specific account; the amount is two Reais per month/student. This initiative considered the importance of intersectionality with the adoption of policies and programs to ensure healthy and adequate food through articulated actions between education and agriculture. This decree also considered the need to 
strengthen fish farming for family farmers. Interviewee ESED02 comments on the benefits of the decree:

"There is a concern on the part of the government to promote family farming, which we already had here through Law No. 3753 [62] and Decree No. 22,177 on fish, we saw that the state, as a state in which fish farming is quite developed. So, we managed to include fish and other foods produced in the state from family farming and cooperatives in school meals and this is very interesting. The return of this is gratifying for those who work in the community project." Interviewee ESED02

There was a new inspection in 2018 by the Ministry of Transparency, Inspection and Control in order to analyze the application of federal resources in the Municipality of Porto Velho. Federal, state and municipal entities were audited. Fieldwork took place from 9 to 17 May for actions in the area of agriculture and from 25 June to 9 August for education. This time the report was more comprehensive and brought contributions to SEMED and SEDUC (MTFC, 2018) [65].

Another important tool that complemented Law No. 11,947 [5] was the Inter-ministerial Ordinance No. 284, of 30 May 2018 [66]. Through this, a list of species of socio-biodiversity was established, for the purpose of marketing in natura or its derived products, within the scope of operations carried out by the PAA, by the Minimum Price Guarantee Policy for Socio-biodiversity Products (PGPMBio), by CONAB, and by the PNAE. Among the items described, 34 are found in the state of Rondônia, but the SEDUC menu includes 9, they are: saffron (tucumã), açaí, cajá, cashew, Brazil nut, cupuaçu, cassava, passion fruit and annatto. Although there are many possibilities to include Amazonian foods, not yet incorporated into school meals, there were advances, as interviewed ESED01 explains:

"To give support, there is an inter-ministerial ordinance that allows the purchase of products, from the local culture, from the northern region of the state. So, there are some products that are regionalized and with this inter-ministerial ordinance, we have already managed to purchase a lot of products." Interviewee ESED01

Finally, the year 2019 was marked by some changes that preceded Resolution No. 6 of 2020 [8]. SEDUC signed the Technical Cooperation Term No. 9969789 with SEAGRI, to address questions about the price of products and inspection of family agriculture suppliers. Training was already being carried out for the introduction of the PNAE card for civil servants and managers in both Departments of Education. SEMED even met with a group of family farmers. Interviewee ESEME03 reports how this change is happening in the Municipal Education Department:

"The old way that FNDE did was to transfer to the municipality, right, and each executing unit, each school, opened an account to receive the transfer. So, every school had an account to receive the transfer. Not now, the difference is that the municipality had to open one account, right. The municipality is going to put an end to these accounts, it is going to apply for corporate cards. I like to compare it to an additional card [ . . . ] actually, SEMED already sent a document in 2019 explaining to principals. For example, School X has this limit ... there's no way to cross this limit. [ ... ] The PMAE, at first its continuation in the traditional way was discussed, then it was decided to use a PMAE card. It will continue in the traditional way until the PNAE card stabilizes. At least 6 months this year, right, so that we can overcome any problems that may arise. And then, next year, the PMAE card." Interviewee ESEME03

A controversial question in PNAE program was the proposition of a PNAE credit card instead foodstuff provision. Interviewee ESEME03 had this point of view:

"It's going to make life easier for everyone, right... Even yesterday I contacted the FNDE, if there is a demand from people who want to trade, but can't get the machine, they made an exception for the transfer, it just has to be very well 
documented that there is no internet where the family farmer is located, the justification for making this exception has to be well founded. But there was also a whole demand, right, which nowadays everyone is already adapted with electronic invoices [ ... ] So this guy who issues electronic invoices, at some point he has access to the internet and then he could possibly also use the machine." Interviewee ESEME03

Interviewee ECFARO01, director of one of the cooperatives, has a more critical stance toward PNAE Card:

"People have their demand and simply apply. And we have to comply. Now there is that partnership that should be on both sides we don't have. They simply handed over the card and didn't even inform ... I went informally to inquire, but no one notified me saying that I needed to adapt or anything. So, I believe that in this sense there should be a better partnership, right, to be able to help because the producer suffers too much to produce even more in Porto Velho, it's not easy. [ ... ] There is a cost, right. It's another bill that the producer will have to pay. I think so ... if it's to improve, I agree, but you also have to look at the producer's situation and I felt that people have not taken this into account." Interviewee ECFARO01

All these changes would happen in 2020, but due to the Coronavirus Pandemic, they were postponed.

\section{Discussion}

While analyzing the norms before and after Law No. 11,947 [5], it is possible to verify the actions that led to questions about the execution of the PNAE. FAE's attempts at decentralization during the 1980s led to the municipalization of resources in the municipality of Porto Velho. State Decree No. 3290 structured the FAPP, with the aim of encouraging farmers. Another relevant aspect was Municipal Decree No. 5251 of 1993 [47], in which SEMED created school councils preparing for school management, that is, in which each school would manage the Program's resources.

In a second moment, decentralization occurred in 1994 with Law No. 8.914, through which some municipalities could be dissociated from the state. In the case of Porto Velho, the municipality has been disassociated. Following trends, CAERO was created in 1997, and in 1998, Provisional Measure No. 1784 [52] authorized the direct transfer of amounts to school councils. During this period, the effects of the new organization of processes were observed.

The third group of events was characterized by actions that sought to respect regional eating habits and the municipality's agricultural vocation. Provisional Measure No. 2178-36 [17] established a percentage for the purchase of agricultural products from the region. While the PAA, instituted by Law No. 10,696 [53], through public calls, instrumentalized the execution of the purchase of family farming. These two actions served to model a solution, setting a precedent for Law No. 11,947 [5].

In a fourth period, characterized by the implementation of the "Sabor do Campo" Project at SEMED and the Commission for Registration of Companies Supplying School Meal Products, at SEDUC in 2007, until the union mobilization Grito da Terra in 2009, a sequence of events occurred that characterized an examination and test phase for the implementation of Law No. 11,647 [5].

There was the institution of Law No. 11,947 [5] in June 2009, then came FNDE Resolutions No. 38 [19] and No. 26 [6], which clarify some points in the execution of the Program. There was resistance from some actors in the Activity System in question, but it was overcome and the change cycle in PNAE continued to stabilize. The sixth moment in this process was marked by municipal and state laws that imprinted regional characteristics on federal public policy. The new practices culminated in FNDE Resolution No. 6 of 2020 [8]. Figure 1 is the expanding spiral of actions analyzed so far. 


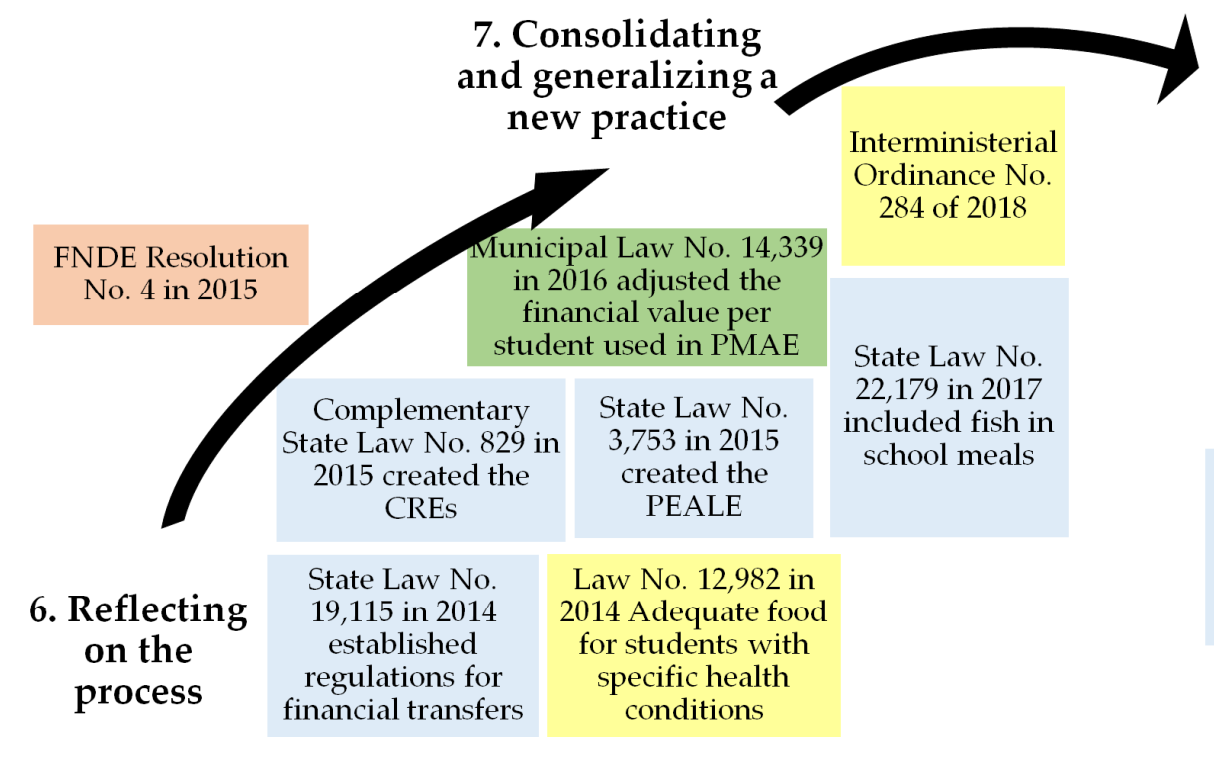

7. Consolidating new practice

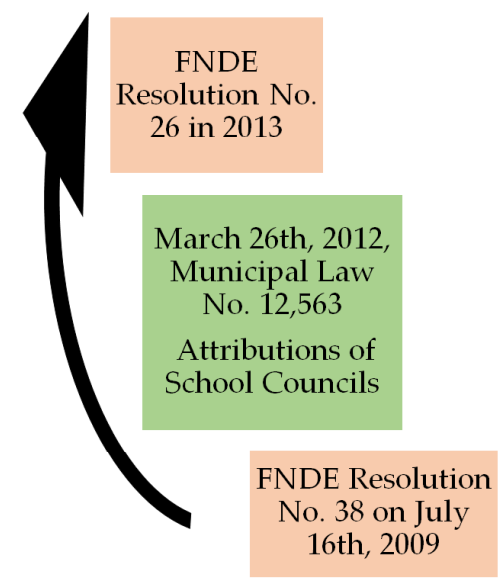

\section{Implementing a} new model

Law No. 11,947
on June 16th,
2009

Law No. 11,947 and FNDE Resolutions

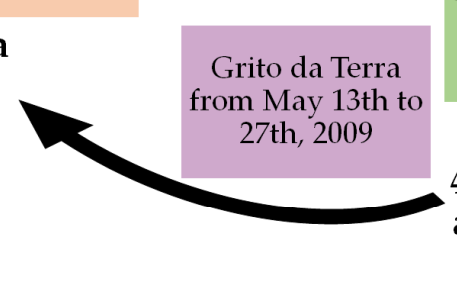

4. Examining and testing a new model
Federal laws and regulations
Union actions - n

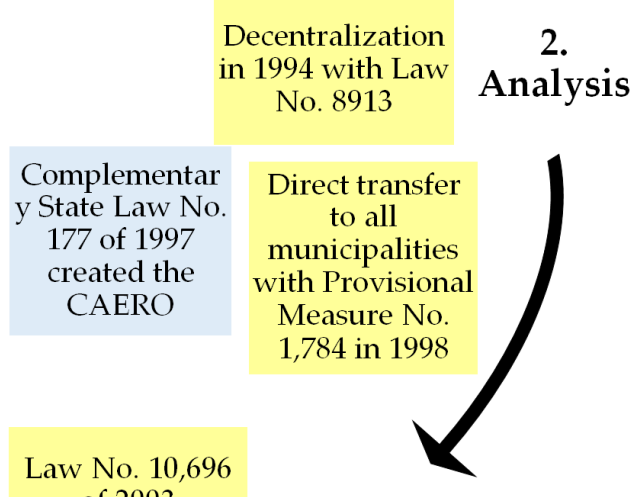
of 2003 institution of the 3. Modeling a PAA 1994 with Law No. 8913

\section{Analysis}

new solution
Resolution No.

6 in 2020

\section{Questioning}
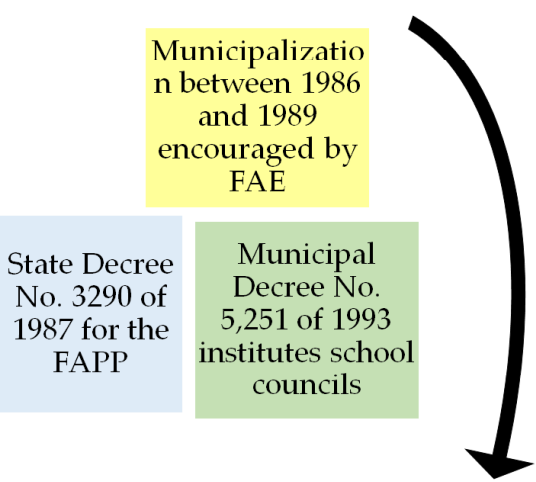

Provisional

Measure No.

2,178 in 2001

Figure 1. Expansive learning cycle of the PNAE in the municipality of Porto Velho. (Source: based on Engeström and Sannino (2010) using own data).

In a second moment, already in an application of the Theory of Expansive Learning it was sought to analyze the data according to the CHAT Matrix of Guiding Questions about who, why, what and how to learn, in order to reconstruct the development of Law No. 11,947 within the structure of an activity and its internal contradictions.

The local history was presented, including the laws, decrees, provisional measures, ordinances and projects that preceded Law No. 11,947 [5] and those that came later, shaping the activity. A collective mediated by artifacts and oriented towards the execution of the PNAE of managers, public servants, nutritionists and union movements was presented. However, there were learnings in other spheres, in this case family farmers and princi- 
pals, units of analysis with a certain independence, but subordinate, understood, within a context.

After the creation of public policies, rural productive inclusion was necessary through the support of technical assistance and extension. This was not limited to a single path; the Ministry of Agrarian Development (MDA) together with the Ministry of Social Development (MDS), now the Ministry of Citizenship, offered courses to strengthen the productivity and trade capacity of family farmers.

About the learning of school administrators, there are interesting reports that some were already in management positions before the institution of Law No. 11,947 [5], so they were able to report the changes that had taken place. Interviewee EMEIEFFP01, principal of a municipal school, says that at the beginning he was resistant, as he did not understand how to buy in the public call model. However, after he came to understand the importance of this in the program, as well as the results in improving school meals, he began to prioritize products from family farming.

Another principal from a municipal school, interviewee EMEFPC01, draws attention to the productive aspect. He emphasizes the importance of interacting with family farmers. Before Law No. 11,947 [5], he said that two-thirds of production was donated or discarded, which is no longer the case in supplying schools.

Asked about training promoted by CECANEs, SEMED's ESEME01 and ESEME02 interviewees mention that there is no nearby CEECANE; what happened was an interaction in 2012 with the Collaborating Center for School Food and Nutrition in Belém, in the state of Pará, where two nutritionists were training. In 2013, another meeting promoted by FNDE, brought together all the nutritionists in the state in the city of Ji-Paraná-RO in training for cooks. In this event, lectures were given on hygiene, proper handling of food, storage techniques and nutritional techniques.

Amidst multiple voices, multiple points of view and interests, there is a division of work, rules and conventions among the participants of the Activity System. This interaction, in turn, can generate problems or innovations, requiring translation and negotiation actions, which emerge to establish a balance between the subjects' duties and rights. The speech of interviewee ECON01 is an example of a voice that represents the interests of farmers, but seeks to reach a consensus with the State:

"The federal government likes to be provoked. By the provocation we say our need, if we keep quiet, the government is going to think that everything is ok. So, we provoke the governments aiming to say what we need. We go to negotiation waiting to be assisted." Interviewee ECON01

The multiple voices are at odds, and build up structural tensions within and between the Activity System. Between the sequence of clashes in the consolidation of Law No.11,947 [5], the most current contradiction is caused by PNAE card. On one hand we have public managers who see better control over the transfers, avoiding fraud, as easier for making accountability reports. However, amidst these advantages, the issue of acquiring the machine to swipe the card arises, and the farmer would have to bear the costs.

FETAGRO has a different opinion. According to interviewee EFET01, even today it is difficult to talk about invoices for the farmer; imagine the introduction of the card machine. In the note, difficulties may occur, such as passion fruit pulp, which is taxed, and guava pulp, which is not taxed, and products such as flour, which suffer a reduction in the calculation base. She also points out that there is no table for filling in the notes, and the farmer has to know when to fill out the note in the system. There are products that, when sold to the final consumer, include $12 \%$ of taxes and the family farmer usually does not know about it.

According to interviewee EFET01, there are two sides. The farmer wants to participate, but who will teach him how to use the card machine? He will have to consider extra costs, with the fees built into this service. In the current scenario, storage and freight are not taken into account, and now this issue comes into play. For her, FETAGRO will have to monitor this issue of the PNAE Card. 
For farmers, the information has been staggered. Many were looking for information, whereas others had more dialogue with schools and had already purchased the equipment. This was the case of the farmer from Association of family farmers in the neighborhood known as Sector Chacareiro, interviewee ESCH03, which serves schools in the state and local network. In early 2020, already had his "card machine".

On the other hand, school principals may encounter some difficulties. The principal of a municipal school, interviewee EMEFBSM01, although she had received the card, had not yet used it. She comments on the adaptations made by suppliers, but believes that her main difficulty will be in the accountability report. She used to pay by online transfer, and through the statements she added up what was spent. With the PNAE card, she will have to sit together with the school treasurer and DIALE to see how they can organize themselves. For example, she does not know if she will be able to access the card movement report.

Another principal of the state network, from Nova California district, believes that the difficulty is not to guide the farmers (the school is served by seven individual farmers), but he points out that the internet signal in the region is unstable, which can interfere a little. This region has a peculiarity; the schools are served by the PNAE and by the PAA, and so, if the farmers are not able to obtain the equipment, there is the possibility of migrating their whole production to the PAA. This has a certain impact on the local economy and even the management of school meals.

As the contradictions of an Activity System grow, questions of established norms begin to arise. In some situations, increased collaboration may occur, which in turn leads to collective change. An example of expansion was the Technical Cooperation Term No. 9969789 between SEDUC and SEAGRI. The need for the term arose due to some difficulties that SEDUC was encountering in making the price quotations for family farming.

In 2019, in order to ensure the control and transparency of public resources, SEDUC started to use a new purchase model for school lunches, the public bidding carried out by the State Procurement Superintendence (SUPEL).

In the previous management model, the school used the Letter of Invitation. A notice was prepared with the needs of the schools, and some companies were invited to participate. A date was established for companies to submit a price bid in an envelope. When the envelopes were opened, suppliers were selected based on the lowest price. There was a limited value for this kind of purchase: 176 thousand Reais per school. However, the main problem was fractionation in the purchases and schools often received a value higher than the limit provided in the invitation letter.

As a result, the number of farmers who served the Secretariat decreased, so there was a need to seek a new pricing policy which would comply with Law No. 11,947 [5] and FNDE resolutions. For this, it was agreed between SEDUC and SEAGRI that the values used in the State PAA would be the same as those used in PNAE and PEALE. The pricing methodology used is regulated by Decree No. 7775 of 4 July 2012 [67] and by MDS Resolution (today, Ministry of Citizenship) No. 59 of 13 July 2013 [68]. The Public Call Notice No. 008/2020/CEL/ SUPEL/RO [69] already presents the values updated within the Cooperation Term established.

The analysis of all the events presented so far is shown in Table 2.

As noted, it found "Who is learning?", "Who has voice in the Activity System?", "Why the members learn?," considering the historicity and contradictions, "What is learned?" and "How they learn?". The expansive cycles generated learning, and this learning maintains settings or adjustments in PNAE. 
Table 2. CHAT guiding questions in the municipality of Porto Velho.

\begin{tabular}{|c|c|c|c|c|c|}
\hline \multirow[t]{2}{*}{ Questions } & \multicolumn{5}{|c|}{ Principles } \\
\hline & Activity Systems & Multiple Voices & Historicity & Contradictions & Expansive Cycles \\
\hline Who is learning? & $\begin{array}{c}\text { Activity System } \\
\text { between Municipal } \\
\text { and State } \\
\text { Managers and } \\
\text { Family Farmers. }\end{array}$ & $\begin{array}{c}\text { Nutritionists, } \\
\text { CAERO, CAEM, } \\
\text { SEDUC, SEMED, } \\
\text { CONTAG, } \\
\text { FETAGRO, } \\
\text { CONSED, } \\
\text { UNDIME. }\end{array}$ & $\begin{array}{c}\text { Municipal and } \\
\text { state managers and } \\
\text { farmers. }\end{array}$ & & $\begin{array}{l}\text { Changes in } \\
\text { attitude of } \\
\text { principals and } \\
\text { farmers. }\end{array}$ \\
\hline Why learn? & $\begin{array}{l}\text { Expansion of the } \\
\text { space for rural } \\
\text { producers. }\end{array}$ & $\begin{array}{l}\text { Balance between } \\
\text { federal standards } \\
\text { and economic and } \\
\text { social needs within } \\
\text { the municipality } \\
\text { Mediation between } \\
\text { local actors. }\end{array}$ & $\begin{array}{l}\text { Historically, } \\
\text { pressures from } \\
\text { government, } \\
\text { unions, civil } \\
\text { society and } \\
\text { associations, } \\
\text { cooperatives, } \\
\text { nutritionists } \\
\text { emerge. }\end{array}$ & $\begin{array}{l}\text { Contradictions } \\
\text { between the } \\
\text { subjects of the } \\
\text { Activity System } \\
\text { regarding rules, } \\
\text { division of labor, } \\
\text { mediational } \\
\text { resources and } \\
\text { Conflicts among } \\
\text { farmers; a } \\
\text { malfunctioning } \\
\text { system attracts } \\
\text { fewer family } \\
\text { producers and } \\
\text { offers students less } \\
\text { healthy food. }\end{array}$ & $\begin{array}{l}\text { Based on federal } \\
\text { legislation, they } \\
\text { create municipal } \\
\text { and state laws that } \\
\text { complement Law } \\
\text { No. } 11947 \text { focusing } \\
\text { on regional } \\
\text { development and } \\
\text { sustainability. }\end{array}$ \\
\hline $\begin{array}{c}\text { What do you } \\
\text { learn? }\end{array}$ & $\begin{array}{l}\text { Law No. 11947, } \\
\text { FNDE Resolutions } \\
\text { and Normative } \\
\text { Instructions. }\end{array}$ & $\begin{array}{l}\text { Rights and duties } \\
\text { of subjects in the } \\
\text { execution of the } \\
\text { PNAE. }\end{array}$ & $\begin{array}{l}\text { Reconcile the laws } \\
\text { for the execution of } \\
\text { the PNAE with } \\
\text { laws for other } \\
\text { processes that } \\
\text { complement the } \\
\text { final result. }\end{array}$ & $\begin{array}{l}\text { Examples of } \\
\text { experiences in } \\
\text { other regions or } \\
\text { departments; } \\
\text { different interests } \\
\text { of participating } \\
\text { actors can be } \\
\text { contradictory }\end{array}$ & $\begin{array}{l}\text { Expansion of } \\
\text { PNAE through the } \\
\text { interaction of the } \\
\text { secretariats, CAEM } \\
\text { and CAERO, } \\
\text { FETAGRO and } \\
\text { CONTAG. }\end{array}$ \\
\hline $\begin{array}{c}\text { How do you } \\
\text { learn? }\end{array}$ & $\begin{array}{l}\text { Working groups, } \\
\text { training offered to } \\
\text { civil servants, } \\
\text { support from } \\
\text { political or union } \\
\text { movements. }\end{array}$ & $\begin{array}{c}\text { Courses promoted } \\
\text { by MDS, MDA, } \\
\text { FNDE and } \\
\text { FETAGRO. }\end{array}$ & $\begin{array}{l}\text { They learn through } \\
\text { historical processes } \\
\text { and analysis of } \\
\text { experiences in } \\
\text { other regions; } \\
\text { including advance } \\
\text { federal decisions. }\end{array}$ & $\begin{array}{l}\text { FNDE, TCU, } \\
\text { CAERO, CGU, } \\
\text { CAEM, MTFC } \\
\text { inspections that } \\
\text { point out errors in } \\
\text { the process. }\end{array}$ & $\begin{array}{l}\text { Learning actions } \\
\text { through } \\
\text { questioning, } \\
\text { analysis, } \\
\text { implementation } \\
\text { and reflection, } \\
\text { including } \\
\text { anticipation of } \\
\text { future behavior. }\end{array}$ \\
\hline
\end{tabular}

Source: based on Engeström (2001, p. 138) using own data.

\section{Conclusions}

During the period analyzed, 37 years, it was exposed how a national public policy was adapted to application at municipal level and how it was organized to meet this demand, as well as how the difference in positions between state and municipality lead to different realities when Law No. 11,947 [5] was adopted and practiced in Porto Velho/RO in the Amazon Region. It is worth mentioning the political origin of this Law because it was created in a left-wing government together with many other programs oriented by environmental and social concerns.

Through all the descriptions, we sought to collect data, information that would support its main objective, which is to analyze how the evolution of Law No. 11,947 [5] promotes expansive learning in the Brazilian National School Feeding Program (NSFP-PNAEPrograma Nacional de Alimentação Escolar) at the municipal level. 
The Theory of Expansive Learning enabled the chronological adjustment of the data collected to analyze the evolution of Law No. 11,947 [5], and, at the same time, its learning phases. For each of its seven phases (Questioning, Analysis, Modeling a new solution, Examination and testing, Implementation of a new model, Reflection on the process and Consolidation and generalization of a new practice) laws, decrees and mobilizations were identified.

Utilizing the TEL approach, it was possible to carry out the actions that led to the ratification of Law No. 11,947 [5], and laws, resolutions, decrees, among the institutions to reach the expansive learning. The findings were organized within the CHAT Guiding Questions Chart, in which it was possible to identify the causes, the reason and the way in which the actors learn within the Activity System, considering their multiple voices, their history, contradictions and expansive cycles. Knowing the Expansive Learning Cycle, enables the mapping of the learnings.

The power of the agency of nutritionists was highlighted for promoting the municipal NSFP-PNAE and space for action depends on the context of each municipality. In the case of SEMED, the nutritionist coordinated the implementation of the PNAE and coordinates the actions between the secretariat, farmers and schools so that the Program continues to be carried out. Meanwhile at SEDUC, from the moment nutritionist RT (responsible technician) took office in 2017, there have been major changes, including with regard to family farming and transparency. It is also worth recognizing the importance of administrative technicians from the secretariats, as they are the ones who study the best way to carry out what the Law requires, and many decisions are taken in conjunction with working groups.

Another important contribution is the participation of social movements and their representative institutions. The union movements contributed to the creation of Law No. 11,947 and act to maintain it, questioning the secretariats' decisions, clarifying points and counterpoints to the farmers. The performance of FETAGRO, for example, influences the price list of the State PAA and the PNAE at SEDUC, while the Rural Workers Union, represented by CONTAG, influences the SEMED price list. During this research, an integration between the PNAE and PAA was noticed, and the existence of a mutual learning process between these two programs, often promoted by union movements.

It was possible to verify the pioneering spirit in the implementation of the PAA in the municipality of Porto Velho even at national level. In Rondônia, the implementation of this public policy was the result of a project by the Rural Workers Union of the Municipality of Porto Velho, encouraged by the then secretary of education in the municipality. According to the representative of the Rural Workers Union, the then secretary of education in the municipality rescued a bill that had been shelved since 1995 from the government of former president Fernando Henrique Cardoso. Five associations were selected to develop the foundations of the initial project to receive the MDS resource. There was even a written proposal made by a SEMED servant who later became secretary of education and who used the knowledge acquired in the project to receive resources from the first PAA, in 2003, to implement the "Sabor do Campo" project in 2007.

"Sabor do Campo", launched on 30 May 2007, included 45 products from family farming in the school menu, even preceding Law 11,947 of 2009 [5]. These facts showed the initiative of institutions and union entities in pioneer projects that later served as model in the country.

Finally, some directions for future studies are described. One important research direction would be to identify the degrees of freedom of each municipality to adapt the rules of the national program along with the capacity of individual agency and collective local participants, and how the learnings of this case could be replicated and adapted for other municipalities. Finally, it would be valuable to research how each municipality could complement with their budget to fulfill $85 \%$ of nutrition needs of the students contemplated by the program. 


\begin{abstract}
Author Contributions: Conceptualization, E.A.d.S. and E.A.P.; methodology, E.A.P. and E.A.d.S.; formal analysis, T.N.d.S., E.A.P. and E.A.d.S.; investigation, E.A.d.S. and E.A.P.; resources, E.A.P.; data curation, E.A.d.S., T.N.d.S. and E.A.P.; writing—original draft, E.A.d.S. and E.A.P.; writing-review and editing, E.A.d.S., T.N.d.S. and E.A.P.; visualization, E.A.d.S.; supervision, E.A.P. and T.N.d.S.; project administration, E.A.P. and T.N.d.S. All authors have read and agreed to the published version of the manuscript.
\end{abstract}

Funding: This research received funding of CNPq. Process number CNPq. 309604/2017-6.

Institutional Review Board Statement: The study was conducted according to the guidelines of the 003/2011CONEP/CNS Brasília-DF, 21 March 2011, and approved by Ethics Committee of Federal University of Rondônia (UNIR) (protocol code CAAE: 29630020.9.0000.5300, valuation $n^{\circ} 3.940 .163$ ).

Informed Consent Statement: Informed consent was obtained from all subjects involved in the study.

Data Availability Statement: Data available on request.

Acknowledgments: We would like to thank the Municipal Secretary of Education of Porto Velho (SEMED), especially the servers of the School Feeding Division (DIALE). We thank the State Department of Education (SEDUC), especially the Department of School Feeding (SAE).

Conflicts of Interest: The authors declare no conflict of interest.

\title{
References
}

1. Fundo Nacional de Desenvolvimento da Educação (FNDE). Programa Nacional de Alimentação Escolar (PNAE). Dados da Agricultura Familiar: Aquisições da Agricultura Familiar no período de 2011 a 2016. Brasília/DF, 2019. Available online: https:/ / www.fnde.gov.br/programas/pnae/pnae-consultas/pnae-dados-da-agriculturafamiliar (accessed on 16 November 2019).

2. Fundo Nacional de Desenvolvimento da Educação (FNDE). Programa Nacional de Alimentação Escolar (PNAE). Sobre o PNAE. Brasília/DF, 2019. Available online: https://www.fnde.gov.br/index.php/programas/pnae/pnae-sobre-oprograma/pnaehistorico (accessed on 16 November 2019).

3. Silva, E.O.; Amparo-Santos, L.; Soares, M.D. Alimentação escolar e constituição de identidades dos escolares: Da merenda para pobres ao direito à alimentação. CSP-Cad. Saúde Pública 2018, 34, 1-13. [CrossRef]

4. Maluf, R.S.J.; Luz, L.F. Sistemas Alimentares Descentralizados: Um Enfoque de Abastecimento na Perspectiva da Soberania e Segurança Alimentar e Nutricional. R. Janeiro, UFRRJ/CPDA/OPPA, 2016, 22 p. (Texto de Conjuntura, 19). Available online: http: / / oppa.net.br/acervo/textos-fao-nead-gpac/Texto \%20de \%20conjuntura $\% 2019 \% 20$ - $\% 20$ Renato $\% 20$ MALUF $\% 20$-\%20Lidiane\%20DA\%20LUZ.pdf (accessed on 1 November 2020).

5. Brasil. Lei Federal n ${ }^{\circ} 11,947$ de 16 de junho de 2009. Diário Oficial [da] República Federativa do Brasil, Brasília, DF, 2009. Available online: http://www.planalto.gov.br/ccivil_03/_Ato2011-2014/2014/Lei/L12982.htm (accessed on 16 August 2020).

6. Brasil. Resolução $n^{\circ}$ 26, de 17 de junho de 2013. Diário Oficial [da] República Federativa do Brasil, Brasília, DF. 2013. Available online: https://www.fnde.gov.br/index.php/acesso-a-informacao/institucional/legislacao/item/4620-resolu\%C3\%A7\%C3 \%A3o-cd-fnde-n\%C2\%BA-26,-de-17-de-junho-de-2013 (accessed on 28 April 2019).

7. Brasil. Resolução $n^{\circ}$ 4, de 3 de abril de 2015. Diário Oficial [da] República Federativa do Brasil, Brasília, DF. 2015. Available online: https://www.fnde.gov.br/index.php/acesso-a-informacao/institucional/legislacao/item/6341-resolu\%C3\%A7\%C3 $\%$ A3o-cd-fnde-mec-n\%C2\%BA-4,-de-3-de-abril-de-2015 (accessed on 28 April 2019).

8. Brasil. Resolução $n^{\circ}$ 6, de 8 de maio de 2020. Diário Oficial [da] República Federativa do Brasil, Brasília, DF. 2020. Available online: http:/ / www.in.gov.br/en/web/dou/-/resolucao-n-6-de-8-de-maio-de-2020-256309972 (accessed on 27 July 2020).

9. Brasil. Lei Federal no 8,666 de 16 de junho de 1993. Diário Oficial [da] República Federativa do Brasil, Brasília, DF. 1993. Available online: http://www.planalto.gov.br/ccivil_03/leis/18666cons.htm (accessed on 27 April 2019).

10. Triches, R.M.; Schneider, S. Alimentação Escolar e agricultura familiar: Reconectando o consumo à produção. Saúde Sociedade 2010, 19, 933-945. Available online: https:/ /www.scielo.br/pdf/sausoc/v19n4/19.pdf (accessed on 17 August 2020). [CrossRef]

11. Instituto Brasileiro de Geografia E Estatística (IBGE). Estimativas Populacionais Para os Municípios e Para as Unidades da Federação Brasileiros em 01.07.2017; Instituto Brasileiro de Geografia E Estatística (IBGE): Brasília, Brazil, 2017. Available online: https: //ibge.gov.br/Estimativas_de_Populacao/Estimativas_2017/estimativa_dou_2017.pdf (accessed on 20 May 2019).

12. Prefeitura Municipal de Porto Velho. Acidade. 2019. Available online: https://www.portovelho.ro.gov.br/artigo/17800/acidade\# (accessed on 23 June 2019).

13. Engeström, Y.; Sannino, A. Studies of expansive learning: Foundations, findings and future challenges. Educ. Res. Rev. 2010, 5, 1-24. Available online: https://www.researchgate.net/publication/248571723_Studies_of_expansive_learning_Foundations_ findings_and_future_challenges (accessed on 26 October 2019). [CrossRef]

14. Engeström, Y. Expansive learning at work: Toward an activity theoretical reconceptualization. J. Educ. Work. 2001, 14, 133-156. Available online: https:/ / www.tandfonline.com/doi/abs/10.1080/13639080020028747 (accessed on 26 October 2019). [CrossRef] 
15. Engeström, Y. Learning by Expanding: An Activity Theoretical Approach to Developmental Research, 2nd ed.; Cambridge University Press: New York, NY, USA, 2015.

16. Peixinho, A.M.L. A trajetória do Programa Nacional de Alimentação Escolar no período de 2003-2010: Relato do gestor nacional. Ciência Saúde Coletiva 2013, 18, 909-916. Available online: http:/ / www.scielo.br/scielo.php?pid=S1413-81232013000400002\& script=sci_abstract\&tlng=pt (accessed on 26 October 2019). [CrossRef]

17. Brasil. Medida Provisória n ${ }^{\circ}$ 2178-36 de 24 de agosto de 2001. Diário Oficial [da] República Federativa do Brasil, Brasília, DF. 2001. Available online: http://www.planalto.gov.br/ccivil_03/MPV/2178-36.htm (accessed on 26 April 2019).

18. Brasil. Portaria Interministerial n ${ }^{\circ} 1010$ de 08 de Maio de 2006. Diário Oficial [da] República Federativa do Brasil, Brasília, DF. 2006. Available online: https://repositorio.observatoriodocuidado.org/bitstream/handle/handle/1554/Portaria\%20\%2 OInterministerial\%20N\%c2\%ba\%201.010_8\%20maio\%202006.pdf?sequence=1\&isAllowed=y (accessed on 28 April 2019).

19. Brasil. Resolução $n^{\circ}$ 38, de 16 de julho de 2009. Diário Oficial [da] República Federativa do Brasil, Brasília, DF. 2009. Available online: http:/ / educacaointegral.mec.gov.br/images/pdf/res_cd_38_16072009.pdf (accessed on 28 August 2020).

20. Das Neves, J. Módulo introdução: Sobre os CECANES's. In Formação de Nutricionista para Atuação no PNAE, 2018, 1st ed.; Mafra, R., Ed.; Centro Colaborador de Alimentação e Nutrição do Escolar de Santa Catarina: Florianópolis, Brazil, 2018; pp. 9-26. Available online: https: / / cecanesc.paginas.ufsc.br/files/2019/07/1.05-Apendice-1.05.-caderno-de-formacao-ead-de-nutricionistas.pdf (accessed on 22 October 2020).

21. Broch, A.E. Congresso Nacional aprova projetos importantes para o MSTTR. J. CONTAG Brasilia 2009, 6, 3. Available online: http:/ / www.contag.org.br/imagens/f1620contagmaiojunho.pdf (accessed on 17 August 2020).

22. Brasil Lei Federal n ${ }^{\circ}$ 10,520, de 17 de julho de 2002. Diário Oficial [da] República Federativa do Brasil, Brasília, DF. 2002. Available online: http://www.planalto.gov.br/ccivil_03/leis/2002/110520.htm (accessed on 17 August 2020).

23. Brasil. Decreto $\mathrm{n}^{\circ}$ 10,024, de 20 de setembro de 2019. Diário Oficial [da] República Federativa do Brasil, Brasília, DF. 2019. Available online: https:/ / www.in.gov.br/en/web/dou/-/decreto-n-10.024-de-20-de-setembro-de-2019-217537021 (accessed on 17 August 2020).

24. Brasil. Lei Federal no 13,987 de 7 de abril de 2020. Diário Oficial [da] República Federativa do Brasil, Brasília, DF, 2020. Available online: https:/ / www.in.gov.br/en/web/dou/- /lei-n-13.987-de-7-de-abril-de-2020-251562793 (accessed on 18 September 2020).

25. Brasil. Resolução ${ }^{\circ}$ 2, de 9 de abril de 2020. Diário Oficial [da] República Federativa do Brasil, Brasília, DF. 2020. Available online: https:/ / www.in.gov.br/en/web/dou/-/resolucao-n-2-de-9-de-abril-de-2020-252085843 (accessed on 18 September 2020).

26. Engeström, Y. From learning environments and implementation to activity systems and expansive learning. Int. J. Hum. Act. Theory 2009, 2, 17-33. Available online: https:/ / core.ac.uk/download/pdf/228665699.pdf (accessed on 26 October 2019).

27. Sannino, A. Activity theory as an activist and interventionist theory. Theory Psychol. 2011, 21, 571-597. Available online: https://journals.sagepub.com/doi/abs/10.1177/0959354311417485 (accessed on 20 January 2020). [CrossRef]

28. Leontiey, A.N. Problems of the Development of the Mind; Progress: Moscow, Russia, 1981.

29. Cole, M. Cultural Psvchology: A Once and Future Discipline; Harvard University Press: Cambridge, MA, USA, 1996.

30. Griffin, P.; Cole, M. Current activity for the future: The Zo-ped. In Children's Learning in the "Zone of Proximal Development", 1st ed.; Rogoff, B., Wertsch, J.V., Eds.; Jossey-Bass: San Francisco, CA, USA, 1984; pp. 45-64.

31. Sampieri, R.H.; Collado, C.F.; Lucio, P.B. Metodologia da Pesquisa, 1st ed.; McGraw-Hill: São Paulo, Brazil, 2006.

32. Merriam, S.B. Introduction to Qualitative Research. Qualitative Research in Practice: Examples for Discussion and Analysis, 1st ed.; Jossey-Bass: San Francisco, CA, USA, 2002.

33. Charreire, S.; Durieux, F. Explorer et tester: Deux voies pour la recherche. In Méthodes de Recherche en Management; Org. Thietart, R.A. et coll; Dunod: Paris, France, 2003; Available online: https://www.dunod.com/sites/default/files/atoms/files/9782100711 093/Feuilletage.pdf (accessed on 20 October 2021).

34. Cruz, L.B. O processo de Formação de Estratégias de Desenvolvimento Sustentável de Grupos Multinacionais. Ph.D. Thesis, Doctorate in Administration. Federal University of Rio Grande do Sul, Porto Alegre, RS, Brazil, 13 November 2007. Available online: https:/ / lume.ufrgs.br/handle/10183/12416 (accessed on 20 October 2020).

35. Yin, R.K. Case Study Research and Applications: Design Methods, 6th ed.; Cosmos Corporation-SAGE: London, UK, 2018.

36. Aaker, D.; Kumar, V.; Day, G. Pesquisa de Marketing, 1st ed.; Atlas: São Paulo, Brazil, 2001.

37. Triviños, A.N. Introdução a Pesquisa em Ciências Sociais: A Pesquisa Qualitativa em Educação, 1st ed.; Atlas: São Paulo, Brazil, 2007.

38. Sandelowski, M. Focus on Research Methods Whatever Happened to Qualitative Description? Res. Nurs. Health 2000, 23, 334-340. [CrossRef]

39. Flick, U. Introdução à Pesquisa Qualitativa, 3rd ed.; Costa, J.E., Translator; Artmed: Porto Alegre, Brazil, 2009.

40. Lofland, J. Styles of reporting qualitative field research. Am. Sociol. 1974, 9, 101-111. Available online: https://www.jstor.org/ stable/27702128?seq=1 (accessed on 22 June 2020).

41. Lofland, J.; Lofland, L.H. Analyzing Social Settings: A Guide to Qualitative Observation and Analysis, 3rd ed.; Wadsworth: Belmont, CA, USA, 1995.

42. Bardin, L. Análise de Conteúdo; Edições 70: São Paulo, Brazil, 2011.

43. Secretaria Municipal de Educação (SEMED). Relatório Anual do Exercício Financeiro de 2019; Porto Velho: Rondônia, Brazil, 2019.

44. Fundo Nacional de Desenvolvimento Da Educação (FNDE). Programa Nacional de Alimentação Escolar (PNAE). Alunado por ação do Programa Nacional de Alimentação Escolar. 2020. Available online: https://www.fnde.gov.br/pnaeweb/publico/ relatorioDelegacaoEstadual.do (accessed on 2 August 2020). 
45. Rondônia. Decreto Estadual n 23,444 , de 18 de dezembro de 2018. Diário Oficial [do] Estado de Rondônia, Porto Velho, RO. 2018. Available online: http:/ / ditel.casacivil.ro.gov.br/COTEL/Livros/Files/D23444.pdf (accessed on 2 August 2020).

46. Spinelli, M.A.S.; Canesqui, A.M. O programa de alimentação escolar no estado do Mato Grosso: Da centralização à descentralização (1979-1995). Rev. Nutr. 2002, 15, 105-117. Available online: https:/ / www.scielo.br/scielo.php?pid=S1415-52732002000100 011\&script=sci_abstract\&tlng=pt (accessed on 14 August 2020). [CrossRef]

47. Porto Velho. Decreto Municipal $n^{\circ}$ 5,251, de 10 de Novembro de 1993; Diário Oficial [do] Município de Porto Velho: Porto Velho, Brazil, 1993.

48. Brasil. Lei n ${ }^{\circ}$ 8,913, de 12 de julho de 1994. Diário Oficial [da] República Federativa do Brasil, Brasília, DF. 1994. Available online: http:/ / www.planalto.gov.br/ccivil_03/LEIS/L8913.htm (accessed on 28 April 2019).

49. Rondônia. Decreto Estadual n 6,681, de 26 de janeiro de 1995. Diário Oficial [do] Estado de Rondônia, Porto Velho, RO. 1995. Available online: http:/ / ditel.casacivil.ro.gov.br/COTEL/Livros/Files/D6681.pdf (accessed on 28 April 2019).

50. Rondônia. Decreto Estadual n ${ }^{\circ}$ 6901, de 22 de junho de 1995. Diário Oficial [do] Estado de Rondônia, Porto Velho, RO. 1995. Available online: http:/ / ditel.casacivil.ro.gov.br/COTEL/Livros/Files/D6901.pdf (accessed on 28 April 2019).

51. Rondônia. Lei Estadual Complementar $n^{\circ}$ 177, de 9 de julho de 1997. Diário Oficial [do] Estado de Rondônia, Porto Velho, RO. 1997. Available online: https:/ / sapl.al.ro.leg.br/media/sapl/public/normajuridica/1997/310/310_texto_integral (accessed on 14 August 2020).

52. Brasil. Medida Provisória n ${ }^{\circ}$ 1,784 de 14 de dezembro de 1998. Diário Oficial [da] República Federativa do Brasil, Brasília, DF, 1998. Available online: http://www.planalto.gov.br/ccivil_03/MPV/Antigas/1784.htm (accessed on 26 April 2019).

53. Brasil. Lei $n^{\circ}$ 10,696, de 2 de julho de 2003. Diário Oficial [da] República Federativa do Brasil, Brasília, DF. 2003. Available online: http:/ / www.planalto.gov.br/ccivil_03/LEIS/2003/L10.696.htm (accessed on 28 April 2019).

54. Valnier, A.; Ricci, F. Programa de Aquisição de Alimentos (PAA): Uma análise comparativa nos estados de Rondônia e Acre. Campo-Território: Rev. Geogr. Agrária 2013, 8, 198-228. Available online: http:/ /www.seer.ufu.br/index.php/campoterritorio/ article/view/217321 (accessed on 2 August 2019).

55. Prefeitura Municipal de Porto Velho. Prefeitura reforça alimentação de alunos do campo. 2019. Available online: https: / / www.portovelho.ro.gov.br/artigo/1974/prefeitura\%EF\%BF\%BEreforca-alimentacao-de-alunos-do-campo (accessed on 23 November 2019).

56. Rondônia. Portaria $\mathrm{n}^{\circ}$ 0323/07-GAB/SEDUC, de 18 de janeiro de 2007. Diário Oficial [do] Estado de Rondônia, Porto Velho, RO. 2007. Available online: http://www.diof.ro.gov.br/data/uploads/diarios-antigos/2007-01-23.pdf (accessed on 17 August 2020).

57. Porto Velho. Decreto Lei Municipal no 12,563, de 26 de março de 2012. Diário Oficial [do] Município de Porto Velho, Porto Velho, RO. 2012. Available online: https://www.portovelho.ro.gov.br/uploads/docman/decreto_n._12.563-12_dispoe_sobre_os_ conselhos_es.pdf (accessed on 24 August 2020).

58. Rondônia. Lei Estadual Complementar $n^{\circ}$ 680, de 7 de setembro de 2012. Diário Oficial [do] Estado de Rondônia, Porto Velho, RO. 2012. Available online: http://www.diof.ro.gov.br/doe/07_SETEMBRO_ESPECIAL.pdf (accessed on 12 August 2020).

59. Brasil. Lei Federal n ${ }^{\circ} 12,982$ de 28 de maio de 2014. Diário Oficial [da] República Federativa do Brasil, Brasília, DF, 2014. Available online: http:/ /www.planalto.gov.br/ccivil_03/_Ato2007-2010/2009/Lei/L11947.htm (accessed on 26 April 2019).

60. Rondônia. Decreto Estadual n 19,115 , de 25 de agosto de 2014. Diário Oficial [do] Estado de Rondônia, Porto Velho, RO. 2014. Available online: http:/ / ditel.casacivil.ro.gov.br/COTEL/Livros/Files/DEC19115.pdf (accessed on 28 April 2019).

61. Rondônia. Lei Estadual Complementar n ${ }^{\circ}$ 829, de 15 de julho de 2015. Diário Oficial [do] Estado de Rondônia, Porto Velho, RO. 2015. Available online: http:// webcache.googleusercontent.com/search?q=cache:OLzkevX5cdUJ:ditel.casacivil.ro.gov.br/ COTEL/Livros /Files/LC829.docx+\&cd=1\&hl=pt-BR\&ct=clnk\&gl=br (accessed on 28 April 2019).

62. Rondônia. Lei Estadual n 3 3,753, de 30 de dezembro de 2015. Diário Oficial [do] Estado de Rondônia, Porto Velho, RO. 2015. Available online: http:/ / ditel.casacivil.ro.gov.br/COTEL/Livros/Files/L3753.pdf (accessed on 28 April 2019).

63. Prefeitura Municipal de Porto Velho. Educação. Available online: https:/ / www.portovelho.ro.gov.br/artigo/23270/educacaoprefeitura-aumentara-em-100-o-repasse-a-merenda-escolar-neste-ano-letivo. (accessed on 23 June 2019).

64. Rondônia. Decreto Estadual n 22,179, de 8 de agosto de 2017. Diário Oficial [do] Estado de Rondônia, Porto Velho, RO. 2017. Available online: http:/ / ditel.casacivil.ro.gov.br/COTEL/Livros/Files/D22179.pdf (accessed on 28 April 2019).

65. Ministério da Transparência, Fiscalização E Controle. Programa de Fiscalização em Entes Federativos-V05 Ciclo Número do Relatório: 201801060. Brasília, MTFC, 2018. Available online: https://eaud.cgu.gov.br/relatorios/?colunaOrdenacao= dataPublicacao\&direcaoOrdenacao=DESC\&tamanhoPagina=15\&offset=0\&titulo=Programa + de + Fiscaliza $\%$ C3 $\%$ A7 $\%$ C $3 \%$ A3 o+em+Entes+Federativos+\%E2\%80\%93+V05\%C2\%BA++Ciclo+N\%C3\%BAmero+do+Relat $\%$ C3\%B3rio $\% 3$ A+201801060\& palavraChave=ROND $\%$ C3\%94NIA $\% 2$ C+SEDUC\#lista (accessed on 17 August 2020).

66. Brasil. Portaria Interministerial n 284 de 30 de maio de 2018. Diário Oficial [da] República Federativa do Brasil, Brasília, DF, 2018. Available online: https:/ / www.in.gov.br/materia/- /asset_publisher/Kujrw0TZC2Mb/content/id/29306868/do1-2018-07-10portaria\%EF\%BF\%BEinterministerial-n-284-de-30-de-maio-de-2018-29306860 (accessed on 17 August 2020).

67. Brasil. Decreto $\mathrm{n}^{\circ} 7,775$, de 4 de julho de 2012. Diário Oficial [da] República Federativa do Brasil, Brasília, DF, 2012. Available online: http:/ / www.planalto.gov.br/ccivil_03/_Ato2011-2014/2012/Decreto/D7775compilado.htm (accessed on 17 August 2020). 
68. Brasil. Resolução $n^{\circ}$ 59, de 13 de julho de 2013. Diário Oficial [da] República Federativa do Brasil, Brasília, DF. 2013. Available online: http://www.lex.com.br/legis_24599200_RESOLUCAO_N_59_DE_10_DE_JULHO_DE_2013.aspx\#: \{\}:text= Estabelece \%20as\%20normas\%20que\%20regem,Alimentos\%2C\%20e\%20d\%C3\%A1\%20outras\%20provid\%C3\%AAncias (accessed on 28 August 2020).

69. Rondônia. Edital de Chamamento Público nº 008/2020/CEL/SUPEL/RO. [Aquisição de gêneros alimentícios da agricultura familiar e do empreendedor familiar rural para o atendimento do Programa Nacional de Alimentação Escolar-PNAE e Programa Estadual de Alimentação Escolar-PEALE]. Rondônia: Superintendência Estadual de Licitações -SUPEL, 2019, 8. Available online: http:/ / www.rondonia.ro.gov.br/licitacao/354223/ (accessed on 2 August 2020). 